\title{
LEVEL OF UNIVERSITY STUDIES AS A FACTOR RELATED TO ACADEMIC PROCRASTINATION IN TEACHER TRAINEES IN THE SLOVAK REPUBLIC
}

\author{
Slávka Krásna ${ }^{1}$, Silvia Barnová ${ }^{2}$, Zuzana Geršicová $^{3}$, Gabriela Gabrhelová ${ }^{4}$
}

\begin{abstract}
Procrastination represents a significant chronic tendency of individuals to delay tasks manifested in various fields of human activities, including their academic life. Even though the results of available research show that almost every student is a procrastinator, in Slovak research, not much attention has been paid to this phenomenon. In the presented paper, the authors deal with the topical issues of academic procrastination in university students enrolled in bachelors and masters teacher training programmes and present the partial results of an original research study in the discussed field according to the variable of the level of university studies. The sample consisted of 748 respondents from the above specific target group and is evenly distributed. For the purposes of the research, an author-constructed questionnaire was used. The results indicate that teacher trainees in master programmes miss deadlines more frequently and they tend to procrastinate in relation to their academic tasks more than their colleagues in bachelor programmes. The presented research brings unique data from the Slovak academic environment and has implications for further research in the field of academic procrastination.
\end{abstract}

UDC Classification: 378, DOI: https://doi.org/10.12955/pss.v2.224

Keywords: procrastination, academic procrastination, teacher trainees.

\section{Introduction}

As assumed by Chovancová (2020), procrastination applies to almost everyone. According to Zengevald (2020), Jarrett (2020), Sirios and Pychyl (2016), Ludwig (2013), and Vion (2016), procrastination represents a significant chronic tendency of an individual to postpone (especially unpleasant) tasks. Gabrhelík et al. (2006) claim that individuals procrastinate when they delay starting or finishing a task. The above authors agree that there is a whole range of forms of procrastination but there is not a generally accepted classification of them. Academic procrastination can be considered an exception.

In this paper, the issues of academic procrastination are dealt with, and the partial results of a research study carried out on a sample of university students enrolled in bachelors and masters teacher training programmes are presented. The aim of the study is to bring unique data on academic procrastination from the Slovak university environment.

\section{Academic Procrastination}

Academic procrastination is related to situations when university students needlessly delay certain academic tasks, such as working on projects, learning for exams, communicating with teachers, etc. (McCloskey \& Scielzo, 2015). Moslemi et al. (2020) and Naturil-Alfonso et al. (2019) define academic procrastination as any irrational, voluntary delay of tasks in the academic environment, which is a common phenomenon among university students influenced by a range of variables (time management, personality traits, etc.). Steel and Klingsieck (2016) found that as many as 95\% of university students have experiences with academic procrastination. In research by Smolová et al. (2017), the prevalence of academic procrastination was surprisingly high as well - almost $100 \%$. Additionally, Gabrhelík's (2008) findings showed that $100 \%$ of respondents were procrastinators and to more than a half of them, a medium degree of academic procrastination was assigned. Based on the above findings, it can be assumed that procrastination is a persisting phenomenon in the academic environment.

\section{Academic Procrastination in Teacher Trainees}

In compliance with already existing research, it can be assumed that the difference between academic procrastination and procrastination in other fields of life lies in its more frequent occurrence. If academic procrastination and chronic procrastination are compared, it must be pointed out that academic procrastination is situationally conditioned (Gabrhelík, 2008; Steel \& Klingsieck, 2016; Smolová et al., 2017; Barnová \& Krásna, 2018, 2019; Barnová et al., 2019a,b). So, university students are at highest

\footnotetext{
${ }^{1}$ DTI University, Department of School Pedagogy and Psychology, Dubnica nad Váhom, Slovakia, krasna@dti.sk

${ }^{2}$ DTI University, Department of School Pedagogy and Psychology, Dubnica nad Váhom, Slovakia, barnova@dti.sk

${ }^{3}$ DTI University, Department of School Pedagogy and Psychology, Dubnica nad Váhom, Slovakia, gersicova@dti.sk

${ }^{4}$ DTI University, Department of Vocational Subject Didactics, Dubnica nad Váhom, Slovakia, gabrhelova@dti.sk
} 
risk and therefore they are included in most definitions of academic procrastination, and hence they are the group at the centre of most researchers' attention. In spite of this, academic procrastination - in the authors' interpretation - may also apply to university teachers or other academically active individuals. Although - based on their research results - most researchers agree that academic procrastination in teacher trainees is, similarly to the case of other groups of university students, a very frequently occurring phenomenon (Pala et al., 2011; Certel et al., 2016; Balkis \& Duru, 2009; Saracaloglu et al., 2018). It must also be mentioned that Akdemir's (2019) findings say that most teacher trainees do not delay their academic tasks, i.e. they do not procrastinate.

In one of the hypotheses of the presented research - using the variable of the level of university studies - the presumption that teacher trainees in bachelors study programmes show statistically significantly lower degrees of academic procrastination than their colleagues in masters study programmes was verified.

\section{Methodology}

Academic procrastination - representing a phenomenon in the academic educational reality - has been at the centre of the authors' attention for a longer period of time, which is reflected in their publication activities presenting the results of a pilot research study and the partial results of their research in the discussed field (Barnová \& Krásna, 2018, 2019; Barnová et al., 2019a,b). The research strategy was realized in the form of a pilot research study in the Slovak Republic. For the purposes of the research, an author-constructed questionnaire was used as there was not any standardized questionnaire available which examined those variables and dimensions that were in compliance with the goals of the realized research. The same applies to the specific target group of university students - pre-service teachers - as there were no research data from the Slovak academic environment in the field of academic procrastination. Based on the results of the pilot study, we can assume that university students' academic procrastination (not exclusively in teacher training programmes) represents a relatively stable issue and foreign research results indicate that it can influence their future careers as it has an impact on their lifelong learning activities in the future. In the presented research study, the most up-to-date partial results of a research study on academic procrastination in teacher trainees in the Slovak Republic are introduced with special attention paid to the variable of the level of university studies dichotomized for bachelors and masters study programmes.

One of the goals of the research was to investigate differences between the degrees of academic procrastination in students according to the variable of their level of university studies (which in this case are bachelors and masters teacher training programmes).

\section{Methods}

Among the research methods, the questionnaire method was applied using Krásna's (2017) questionnaire "Academic Procrastination of University Students". The questionnaire was administered online. In the research study, five basic variables (socio-demographic data) were worked with - gender, age, form of study, level of university studies, and the type of university (public or private). From the above five variables, eight new variables were calculated using dichotomization.

\section{Research Tool}

The author-constructed questionnaire is focused on general and academic procrastination, it leads the respondents towards reflection about their prevailing behaviour in their private life and subsequently in their academic life. The respondents indicate their answers on 5-point Likert scales ranging from 5 always to 1 -never. The questionnaire consists of two dimensions - General Procrastination (Cronbach's Alpha $=0.862)$ and Academic Procrastination with four further dimensions of academic procrastination (Lessons, Preparation for Exams, Time Management, and Administrative Tasks) with 20 items (each dimension is investigated into by five questionnaire items) - Cronbach's Alpha $=0.947$. Based on the calculated reliability of both parts of the questionnaire, it can be assumed that the author-constructed questionnaire demonstrates high internal consistency, it is reliable, and the obtained data is valuable and well interpretable.

\section{Research Sample}

Intentional and available sampling was used, and the respondents completed the questionnaire voluntarily. 748 respondents in total were included in the research sample. Among them, 439 (58.69\%) 
were female and $309(41.31 \%)$ were male teacher trainees. The age of the respondents ranged from 18 to 59 years old with the average age being 34 years old. The sample consisted of 378 (50.5\%) younger respondents aged between 18 and 34 years old and $370(49.5 \%)$ respondents aged between 35 and 59 years old. The questionnaire was completed by $353(47.2 \%)$ students in bachelor study programmes and $395(52.8 \%)$ students in master study programmes. Among them, $315(42.1 \%)$ students took part in internal study programmes and $433(57.9 \%)$ of them were external students. $394(52.7 \%)$ respondents studied at public universities and 354 (47.3\%) at private universities.

The research sample is evenly distributed in all observed variables and the obtained results can be considered valuable, reliable and valid for the research sample. The validity of the results for the specific target group of all university students in teacher training programmes in the Slovak conditions is limited.

\section{Results and Discussion}

Using SPSS, in each dimension of academic procrastination, statistically significant differences were calculated (see Table 1, Table 2, and Figure 1).

Table 1: Descriptive Statistics - Academic Procrastination from the Aspect of Dimensions According
to the Variable of the Level of University Studies
\begin{tabular}{|l|r|r|r|r|r|r|r|r||}
\hline & \multicolumn{2}{|c|}{$\mathbf{N}$} & \multicolumn{2}{|c|}{ Mean } & \multicolumn{2}{c|}{ Std. Deviation } & \multicolumn{1}{c|}{ Std. Error Mean } \\
\cline { 2 - 11 } & Bachelor & Master & Bachelor & Master & Bachelor & Master & Bachelor & Master \\
\hline Academic Procrastination & 353 & 395 & 2.14 & 2.26 & 0.81 & 0.74 & 0.04 & 0.04 \\
\hline Lessons & 353 & 395 & 2.27 & 2.46 & 0.98 & 0.93 & 0.05 & 0.05 \\
\hline Preparation for Exams & 353 & 395 & 2.21 & 2.33 & 0.90 & 0.78 & 0.05 & 0.04 \\
\hline Time Management & 353 & 395 & 2.08 & 2.19 & 0.81 & 0.76 & 0.04 & 0.04 \\
\hline Administrative Tasks & 353 & 395 & 2.01 & 2.06 & 0.79 & 0.79 & 0.04 & 0.04 \\
\hline
\end{tabular}

Source: Authors

Figure 1: Descriptive Statistics - Academic Procrastination from the Aspect of Dimensions According to the Variable of the Level of University Studies

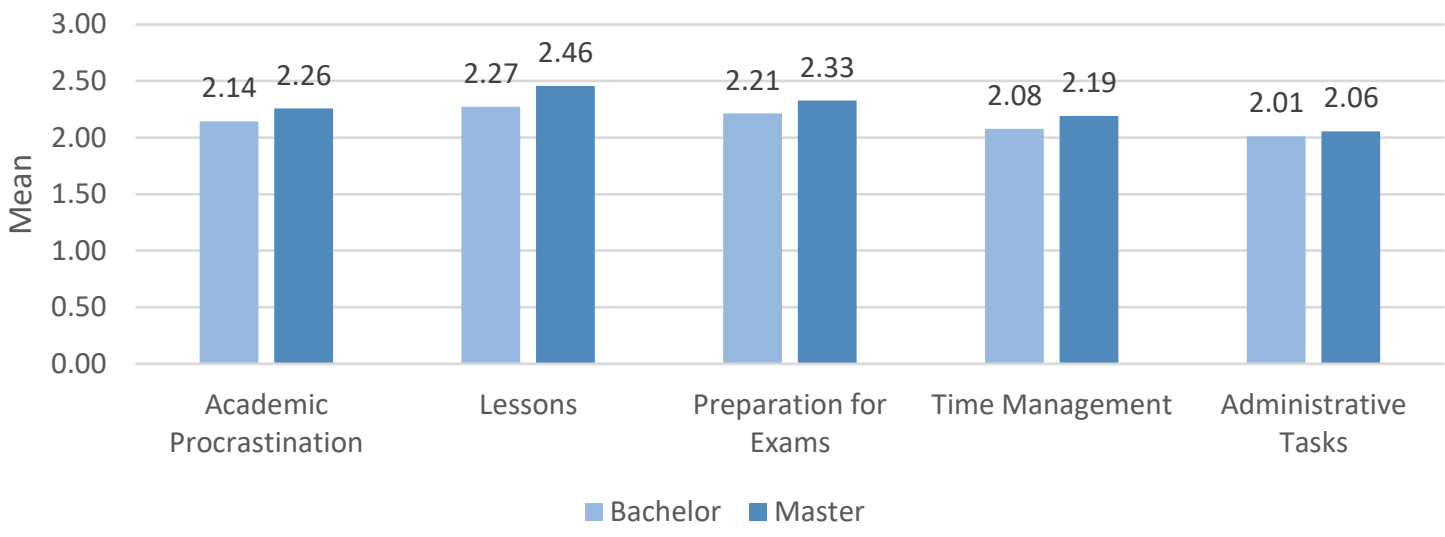

Source: Authors

Table 2: Tests of Statistical Hypotheses from the Aspect of Dimensions

\begin{tabular}{|c|c|c|c|c|c|c|c|}
\hline & \multicolumn{7}{|c|}{ t-test for Equality of Means } \\
\hline & \multirow[b]{2}{*}{$\mathbf{T}$} & \multirow[b]{2}{*}{ Df } & \multirow{2}{*}{$\begin{array}{l}\text { Sig. (2- } \\
\text { Tailed) }\end{array}$} & \multirow{2}{*}{$\begin{array}{c}\text { Mean } \\
\text { Difference }\end{array}$} & \multirow{2}{*}{$\begin{array}{l}\text { Std. Error } \\
\text { Difference }\end{array}$} & \multicolumn{2}{|c|}{$\begin{array}{l}\text { 95\% Confidence } \\
\text { Interval of the } \\
\text { Difference }\end{array}$} \\
\hline & & & & & & Lower & Upper \\
\hline $\begin{array}{l}\text { Academic } \\
\text { Procrastination }\end{array}$ & -2.016 & 746 & 0.044 & -0.11383 & 0.05645 & -0.22465 & -0.00300 \\
\hline Lessons & -2.610 & 746 & 0.009 & -0.18198 & 0.06972 & -0.31885 & -0.04511 \\
\hline Preparation for Exams & -1.878 & 746 & 0.061 & -0.11501 & 0.06124 & -0.23523 & 0.00521 \\
\hline Time Management & -1.987 & 746 & 0.047 & -0.11446 & 0.05760 & -0.22754 & -0.00138 \\
\hline Administrative Tasks & -0.760 & 746 & 0.448 & -0.04386 & 0.05774 & -0.15722 & 0.06950 \\
\hline
\end{tabular}


Table 1 and Table 2 show that teacher trainees in masters study programmes procrastinate in the academic environment significantly more than teacher trainees in bachelors study programmes $(\mathrm{p}=0.05)$. The findings revealed that from the aspect of the level of the university study programme, no significant differences were found in the dimensions "Preparation for Exams" and "Administrative Tasks".

As it can be seen in Table 1 and Table 2 that teacher trainees in masters programmes indicated statistically higher degrees of academic procrastination in the dimension "Lessons" $(p=0.001)$ than students in bachelors study programmes. The same applies to the dimension of "Time Management" where students in masters study programmes showed significantly higher degree of academic procrastination $(\mathrm{p}=0.05)$ compared to students in bachelors study programmes. Teacher trainees in masters study programmes missed deadlines more frequently.

\section{Conclusion}

The above findings - i.e. higher degrees of academic procrastination in teacher trainees in masters study programmes compared with teacher trainees in bachelors study programmes - can have several possible explanations. One of them lies in the fact that bachelors programmes are often subjectively perceived by students as more demanding, which means that they are associated with higher degrees of anxiety related to the process of getting used to the new academic environment. Many academic activities are new to students, therefore, they possibly demonstrate higher levels of academic humility and show more respect to authorities when performing academic activities.

The findings of the presented research correspond with the results of foreign research on academic procrastination in teacher trainees (e.g. Certel et al., 2016; Saracaloglu et al., 2018). The results show that students in masters study programmes procrastinate significantly more than students in bachelors study programmes, i.e. more experienced students have a greater tendency towards procrastination.

In the field of pre-service teachers' academic procrastination, further research focusing on the factors in academic environments having a direct impact on the results according to the variable of the level of university studies should be carried out as it is a phenomenon which can be decisive not only from the aspect of each teacher trainees' future career, but also from the aspect of their future students' learning habit development.

\section{Acknowledgement}

The authors gratefully acknowledge the contribution of DTI University in Dubnica nad Váhom, Slovakia under the project IGA 02DTI/2020 "University Students' Academic Procrastination".

\section{References}

Akdemir, Ö. A. (2019). Academic procrastination behaviors of preservice teachers in Turkish context. World Journal of Education, 9(2), 13-21.

Balkis, M., \& Duru, E. (2017). Gender Differences in the Relationship Between Academic Procrastination, Satisfaction with Academic Life and Academic Performance. https://doi.org/10.13140/rg.2.2.23164.64640

Barnová, S., \& Krásna, S. (2018). Academic procrastination - One of the barriers in lifelong learning. R\&E SOURCE. Online Journal for Research and Education, 13, Special Issue, 8-12.

Barnová, S., \& Krásna, S. (2019). Prokrastinácia ako copingová stratégia študentov vysokých škôl [Procrastination as a Coping Strategy in University Students]. In M. Horváth (Ed.), Socialium Actualis V (pp. 7-25). Týn nad Vltavou: Nová Forma.

Barnová, S., Krásna, S., \& Gabrhelová, G. (2019a). Akademická prokrastinácia pracujúcej populácie ako bariéra v rámci terciárneho vzdelávania [Academic Procrastination of the Working Population as a Barrier in Tertiary Education]. In H. Majdúchová et al., Aktuálne problémy podnikovej sféry 2019 (pp. 23-34). Bratislava: EKONÓM.

Barnová, S., Krásna, S., \& Gabrhelová, G. (2019b). Academic procrastination as a coping strategy of adults involved in lifelong learning. In L. Gómez Chova, A. López Martínez, I. Candel Torres (Eds.), Edulearn 2019 Proceedings (pp. 71467151). IATED Academy.

Certel, Z., Bahadir, Z., \& Özgonu, L. M. (2016). Investigation of academic procrastination and academic self-efficacy of physical education and sport teacher candidates in term of some variables. Turkish Online Journal of Educational Technology, 1295-1300.

Chovancová, Z. (2020). Prečo prokrastinujeme? Niekol'ko vedeckých faktov a tipov [Why Do We Procrastinate? Several Scientific Facts and Tips]. Retrieved from https://www.welcometothejungle.com/sk/articles/preco-prokrastinujeme-niekolkovedeckych-faktov-a-tipov

Gabrhelík, R., Vacek, J., \& Miovský, M. (2006). Prokrastinace: validizace sebeposuzovací škály na populaci studenti̊ vysokých škol [Procrastination: Validation of the Self-Evaluation Scale on the Population of University Students] Československá psychologie, 50(4), 361-371. 
Gabrhelík, R. (2008). Akademická prokrastinace: ověření sebeposuzovaci škály, prevalence a př́činy prokrastinace [Academic Procrastination: Verification of the Self-Evaluation Scale, Prevalence and Causes of Procrastination] (Disertation thesis). Brno: Masarykova univerzita, Fakulta sociálních studií, Katedra psychologie. Retrieved from https://is.muni.cz/th/114738/fss_d/Proc_disertace_gab.pdf

Jarrett, C. (2020). Why procrastination is about managing emotions, not time? Retrieved from https://www.bbc.com/worklife/article/20200121-why-procrastination-is-about-managing-emotions-not-time

Krásna, S. (2017). Dotazník Akademickej prokrastinácie vysokoškolských študentov [Questionnaire on University Students' Academic Procrastination]. Retrieved from https://docs.google.com/forms/d/e/1FAIpQLSd726r3dvxJuENMXNuV4KpZIa0Ht3lktbrLmgS4uyd4lyahA/viewform?usp=sf_link

Ludwig, P. (2013). Konec prokrastinace: jak přestat odkládat a začit žit naplno [End of Procrastination: How to Stop Delaying and Start Living Fully]. Brno: Jan Melvil.

McCloskey, J., \& Scielzo, S. A. (2015). Finally! The Development and Validation of the Academic Procrastination Scale. Retrieved from https://doi.org/10.13140/rg.2.2.23164.64640

Moslemi, Z., Ghomi, M., \& Mohammadi, D. (2020). The relationship between personality dimensions (neuroticism, conscientiousness) and Self-esteem with Academic procrastination among students at Qom University of Medical Sciences. Development Strategies in Medical Education, 7(1), 5-16.

Naturil-Alfonso, C., Peñaranda, D. S., Vicente, J. S., \& Marco-Jiménez, F. (2018). Procrastination: The poor time management among university students. In 4th International Conference on Higher Education Advances (HEAd'18). Valencia: Universitat Polit ecnica de Val'encia, Val’encia. http://dx.doi.org/10.4995/HEAd18.2018.8167

Pala, A., Akyildiz, M., \& Bagci, C. (2011). Academic procrastination behaviour of pre-service teachers' of Celal Bayar University. Procedia - Social and Behavioral Sciences, 29, 1418-1425. http://dx.doi.org/10.1016/j.sbspro.2011.11.381

Saracaloglu, A. S., Dincer, B., \& Gerceker, C. S. (2018). The relationship between music teacher candidates' academic and general procrastination tendencies and test anxiety. Journal of Education and Training Studies, 6(9), 174-183.

Sirios, F. M., \& Pychyl, T. A. (Eds). (2016). Procrastination, Health and Well-Being. London: Elsevier Academic Press.

Smolová, H., Kubová, P., \& Urbancová, H. (2017). Akademická prokrastinace studentů VŠEM [Academic Procrastination in VŠEM Students]. Ekonomické Listy, 8(6), 63-77.

Steel, P., \& Klingsieck, K. B. (2016). Academic Procrastination: Psychological Antecedents Revisited. https://doi.org/10.1111/ap.12173

Vion, J. (2016). Que faire pour lutter contre la procrastination? [What to Do to Combat Procrastination?]. Retrieved from https://www.neuropro-consulting.fr/que-faire-pour-lutter-contre-la-procrastination/

Zengevald, P. (2020). Prokrastinácia nie je o správnom rozvrhnutí času. V čom teda spočíva tajomstvo úspechu? [Procrastination is not about Good Time Management. What Is the Secret of Success?]. Retrieved from https://www.startitup.sk/prokrastinacia-nie-je-o-spravnom-rozvrhnuti-casu-v-com-teda-spociva-tajomstvo-uspechu/ 